\title{
PENGARUH KEBIJAKAN DIVIDEN, LIKUIDITAS, NET PROFIT \\ MARGIN, RETURN ON EQUITY, DAN PRICE TO BOOK VALUE TERHADAP HARGA SAHAM PADA PERUSAHAAN MANUFAKTUR YANG TERDAFTAR DI BURSA EFEK INDONESIA $2010-2013$
}

\author{
Thio Lie Sha \\ Fakultas Ekonomi Universitas Tarumanagara \\ Email: thioliesha@yahoo.com
}

\begin{abstract}
This research aimed to analyze the effect of Dividend Policy, Liquidity, NPM, ROE, and PBV on stock prices of manufacturing companies in $2010-2013$. Samples were manufacturing companies that listed in Indonesia Stock Exchange in 2010 - 2013. This research uses 72 data with 18 selected companies per year. The analysis tool used in this research is multiple linear regression using SPSS computer program version 21.0. The results show that Dividend Policy, Liquidity, NPM, ROE, and PBV jointly have significantly affected the stock price. Partially, Dividend Policy have significantly affected the stock price, whereas Liquidity, NPM, ROE, and PBV have not significantly affected the stock price.
\end{abstract}

Key word: Dividend Policy, Liquidity, Net Profit Margin, Return on Equity, Price to Book Value, Stock Price

\begin{abstract}
Abstrak: Penelitian ini bertujuan untuk menganalisis pengaruh Kebijakan Dividen, Likuiditas, NPM, ROE, dan PBV terhadap harga saham pada perusahaan manufaktur pada tahun 2010-2013. Sampel penelitian ini adalah perusahaan manufaktur yang terdaftar di Bursa Efek Indonesia padatahun 2010 - 2013. Penelitian ini menggunakan 72 data dengan 18 perusahaan yang dipilih per tahun. Alatanalisis yang digunakan dalam penelitian ini adala hanalisis linier berganda dengan menggunakan program komputer SPSS versi 21.0. Hasil penelitian menunjukkan bahwa secara bersama-sama, Kebijakan Dividen, Likuiditas, NPM, ROE, dan PBV mempunyai pengaruh yang signifikan terhadap harga saham. Secara parsial, Kebijakan Dividen mempunyai pengaruh yang signifikan terhadap harga saham, sedangkan Likuiditas, NPM, ROE, dan PBV tidak berpengaruh signifikan terhadap harga saham.
\end{abstract}

Kata kunci: Kebijakan Dividen, Likuiditas, Net Profit Margin, Return on Equity, Price to Book Value, Harga Saham

\section{PENDAHULUAN}

Pada zaman modern ini, suatu perusahaan diwajibkan untuk melakukan inovasi, ekspansi, dan selalu berusaha untuk meningkatkan kinerjanya agar dapat bersaing dengan kompetitor-kompetitornya. Demi melakukan inovasi dan ekspansi, suatu perusahaan memerlukan tambahan modal yang jumlahnya tidak sedikit. Salah satu sarana untuk mendapatkan tambahan modal tersebut melalui pasar modal yang ada di Indonesia yaitu 
Bursa Efek Indonesia (BEI). Secara umum perusahaan menerbitkan saham yang dapat dimiliki oleh setiap investor guna memperoleh tambahan modalnya.

Harga saham suatu perusahaan ditentukan oleh demand dansupply antara penjual dan pembeli. Biasanya demand dansupply ini dipengaruhi baik oleh faktor internal maupun eksternal perusahaan. Faktor internal merupakan faktor yang berhubungan dengan tingkat kinerja perusahaan yang dapat dikendalikan oleh manajemen perusahaan. Faktor internal tersebut seperti kebijakan dividen, likuiditas perusahaan, profitabilitas, rasio utang dan equity, serta rasio keuangan lainnya. Sedangkan faktor eksternal merupakan hal-hal di luar kemampuan manajemen perusahaan untuk mengendalikannya, seperti adanya isu politik, perubahan kurs, laju inflasi yang tinggi, tingkat suku bunga deposito, dan lain-lain.

Bagi investor yang menanamkan dananya dalam bentuk saham perlu mempertimbangkan informasi yang relevan dengan kondisi pasar modal sehingga dapat terhindar dari kesalahan pengambilan keputusan untuk berinvestasi. Salah satu informasi yang diperlukan oleh investor adalah laporan keuangan perusahaan, dimana laporan keuangan biasanya dapat mencerminkan kondisi keuangan perusahaan. Kondisi keuangan inilah yang menentukan kemampuan perusahaan untuk membayar dividen tanpa adanya risiko kebangkrutan.Maka dari itu, investor harus memilih perusahaan yang mempunyai reputasi yang baik. Perusahaan yang mempunyai reputasi baik biasanya mampu memberikan dividen secara konstan kepada pemegang saham. Semakin meningkatnya laba yang diterima perusahaan maka semakin tinggi pula dividen yang dibayarkan perusahaan kepada pemegang saham.

Investor dalam melakukan analisisnya biasanya memilih industri manufaktur sebagai objeknya karena industri manufaktur merupakan salah satu sektor utama di Bursa Efek Indonesia (BEI) yang dapat mencerminkan keadaan pasar modal. Selain jumlah perusahaannya yang banyak, rata-rata investor lebih memilih untuk berinvestasi pada perusahaan manufaktur, karena harga saham perusahaan manufaktur selalu meningkat setiap tahunnya.

Menurut penelitian yang dilakukan oleh Rescyana Putri Hutami (2012: 120) Dividend per Share (DPS), Return on Equity(ROE), Net Profit Margin (NPM) secara signifikan mempengaruhi harga saham. Menurut Jeany Clarensia, Sri Rahayu, dan Nur Azizah (2011: 87) variabel likuiditas dan kebijakan dividen secara signifikan mempengaruhi harga saham. Lalu menurut Yogi Permana (2009 :6) Price to Book Value (PBV) secara signifikan mempengaruhi harga saham.

Namun menurut penelitian Tita Deitiana (2011:65) likuiditas dan kebijakan dividen tidak mempengaruhi harga saham secara signifikan. Menurut Ina Rinati (2012:10) Net Profit Margin(NPM) dan Return on Equity(ROE) tidak mempengaruhi harga saham secara signifikan. Menurut Stella (2009:105) Price to Book Value(PBV) tidak mempengaruhi harga saham secara signifikan. Kemudian menurut Serife Ozlen (2014:599) likuiditas, Net Profit Margin(NPM), dan Price to Book Value(PBV) dapat secara signifikan dan tidak signifikan mempengaruhi harga saham, tergantung dari sektor perusahaan yang diteliti.

Berdasarkan informasi yang telah didapat dan observasi yang telah dilakukan, maka dapat diidentifikasikan masalah apakah kebijakan dividen, likuiditas, Net Profit Margin (NPM), Return on Equity (ROE), dan Price to Book Value (PBV) berpengaruh terhadap harga saham.

Dalam penelitian ini, hanya dilakukan penelitian atas faktor-faktor yang mempengaruhi harga saham. Faktor-faktor tersebut adalah kebijakan dividen, likuiditas, Net Profit Margin (NPM), Return on Equity (ROE), dan Price to Book Value (PBV). Oleh 
karena terbatasnya waktu dan kemampuan, penelitian ini dibatasi hanya pada perusahaan manufaktur yang terdaftar di Bursa Efek Indonesia (BEI) pada tahun 2010-2013.

Masalah yang akan dibahas pada penelitian ini adalah: (1) Apakah terdapat pengaruh kebijakan dividen terhadap harga saham pada perusahaan manufaktur di Bursa Efek Indonesia (BEI); (2) Apakah terdapat pengaruh likuiditas terhadap harga saham pada perusahaan manufaktur di Bursa Efek Indonesia (BEI); (3) Apakah terdapatpengaruh Net Profit Margin (NPM) terhadap harga saham pada perusahaan manufaktur di Bursa Efek Indonesia (BEI); (4) Apakah terdapatpengaruh Return on Equity (ROE) terhadap harga saham pada perusahaan manufaktur di Bursa Efek Indonesia (BEI); (5) Apakah terdapatpengaruh Price to Book Value (PBV) terhadap harga saham pada perusahaan manufaktur di Bursa Efek Indonesia (BEI).

Penelitian ini bertujuan untuk membuktikan secara empiris fenomena yang berkaitan dengan kebijakan dividen, likuiditas, Net Profit Margin (NPM), Return on Equity (ROE), Price to Book Value (PBV), dan harga saham pada perusahaan manufaktur di Bursa Efek Indonesia(BEI) tahun 2010-2013. Oleh karena itu, tujuan penelitian ini adalah untuk: (1) Menganalisis pengaruh kebijakan dividen terhadap harga saham pada perusahaan manufaktur di Bursa Efek Indonesia (BEI); (2) Menganalisis pengaruh likuiditas terhadap harga saham pada perusahaan manufaktur di Bursa Efek Indonesia (BEI); (3) Menganalisis pengaruh Net Profit Margin (NPM) terhadap harga saham pada perusahaan manufaktur di Bursa Efek Indonesia (BEI); (4) Menganalisis pengaruh Return on Equity (ROE) terhadap harga saham pada perusahaan manufaktur di Bursa Efek Indonesia (BEI); (5) Menganalisis pengaruh Price to Book Value (PBV) terhadap harga saham pada perusahaan manufaktur di Bursa Efek Indonesia (BEI).

\section{KAJIAN TEORI}

Laporan Keuangan. Terdapat beberapa definisi yang berkaitan dengan laporan keuangan. Menurut Standar Akuntansi Keuangan No.1 (2012:2), "Laporan keuangan adalah suatu penyajian terstruktur dari posisi keuangan dan kinerja keuangan suatu entitas".

Menurut Sofyan S. Harahap, dalam buku Analisa Kritis Atas Laporan Keuangan (2006:105), "Laporan keuangan adalah laporan yang menggambarkan kondisi keuangan dan hasil usaha suatu perusahaan pada saat tertentu atau jangka waktu tertentu". Menurut Kieso, Weygandt, dan Warfield (2011:4) laporan keuangan didefinisikan sebagai berikut :

"Financial statement are the principal means through which a company communicates its financial information to those outside it. These statements provide a company's history quantified in money terms. The financial statements most frequently provided are (1) the balance sheet, (2) the income statement, (3) the statement of cash flows, and (4) the statement of owners' or stockholders' equity. Note disclosures are an integral part of each financial statement".

Berdasarkan beberapa definisi di atas dapat ditarik kesimpulan bahwa laporan keuangan merupakan laporan yang menyajikan posisi keuangan entitas yang memberikan informasi kepada pihak yang berkepentingan mengenai data-data yang berkaitan dengan kondisi keuangan, kinerja keuangan, dan hasil usaha suatu entitas, dimana umumnya laporan ini meliputi neraca, laporan laba rugi, laporan perubahan modal, laporan arus kas, serta catatan atas laporan keuangan yang merupakan bagian integral dari laporan keuangan. 
Tujuan Laporan Keuangan. Menurut Kieso, Weygandt, dan Warfield (2011:5) tujuan laporan keuangan diuraikan sebagai berikut:

"The objective of general-purpose financial reporting is to provide financial information about the reporting entity that is useful to present and potential equity investors, lenders, and other creditors in decisions about providing resources to the entity".

Sugiono, Soenarno, dan Kusumawati (2010: 8) berpendapat:

"Tujuan laporan keuangan dimaksudkan untuk berguna dalam pengambilan keputusan ekonomi melalui kredit dan investasi. Tujuan selanjutnya untuk menampilkan sumber daya perusahaan, klaim atas sumber daya tersebut dan perubahan antara keduanya".

Berdasarkan uraian di atas, maka dapat disimpulkan bahwa tujuan laporan keuangan adalah untuk memberikan informasi keuangan suatu entitas yang dapat dijadikan pertimbangan investor, kreditur, dan pemberi pinjaman dalam mengambil keputusan untuk terlibat dengan entitas tersebut. Selain itu laporan keuangan juga dapat digunakan manajemen untuk memproyeksikan sumber daya yang digunakan oleh entitas.

Menurut Standar Akuntansi Keuangan No. 1 (2012: 6), Laporan keuangan yang lengkap terdiri dari komponen-komponen berikut ini: (1) Laporan posisi keuangan (neraca) pada akhir periode; (2) Laporan laba rugi komprehensif selama periode; (3) Laporan perubahan ekuitas selama periode; Laporan arus kas selama periode; Catatan atas laporan keuangan, berisi ringkasan kebijakan akuntansi penting dan informasi penjelasan lain; (4) Laporan posisi keuangan pada awal periode komparatif yang disajikan ketika entitas menerapkan suatu kebijakan akuntansi secara retrospektif atau membuat penyajian kembali pos-pos laporan keuangan, atau ketika entitas mereklasifikasi pos-pos dalam laporan keuangannya.

Dividen. Salah satu alasan investor membeli saham adalah dividen. Berikut beberapa definisi dividen, menurut Sjahrial dalam Clarensia, Rahayu, dan Azizah (2013:77) "Seluruh laba yang diperoleh perusahaan sebagian dibagikan kepada pemegang saham berupa dividen". Menurut Weygandt, Kieso, dan Kimmel (2009:596) "A dividend is a corporation's distribution of cash or stock to its stockholders on a pro rata (proportional) basis". Lalu menurut Deitiana dalam Clarensia, Rahayu, dan Azizah (2013:77)

"Dividen adalah pembagian laba perusahaan yang besarnya telah ditetapkan dalam Rapat Umum Pemegang Saham (RUPS) kepada para pemegang saham secara proporsional sesuai dengan jumlah saham yang dimiliki oleh masing-masing pemegang saham tersebut".

Maka dividen dapat diartikan sebagai suatu imbalan perusahaan yang pada umumnya berupa uang atau saham berdasarkan laba yang diperoleh perusahaan yang diberikan kepada pemegang sahamnya secara proporsional sesuai dengan jumlah saham yang dimiliki.

1. Dividend Per Share (DPS). Menurut Weston dan Copeland dalam Hutami (2012: 109), "Dividend per share merupakan total semua dividen tunai yang dibagikan kepada pemegang saham dibandingkan dengan jumlah saham yang beredar". Menurut Sarngadharan dan Kumar (2011: 148), "Dividend per Share (DPS) shows the dividend distributed by the company out of the earnings available to the equity shareholders, on per share basis". 
Maka dapat disimpulan Dividend per Share (DPS) merupakan total dividen tunai yang dibagikan perusahaan berdasarkan laba yang tersedia kepada pemegang saham dibandingkan dengan jumlah saham yang beredar.

2. Dividend Payout Ratio (DPR). Menurut Keown dalam Deitiana (2011:62), "Rasio pembayaran dividen adalah jumlah dividen yang dibayarkan relatif terhadap pendapatan bersih perusahaan atau pendapatan tiap lembar". Menurut Hin dalam Deitiana (2011:61), "Dividend Payout Ratio merupakan perbandingan dividen yang diberikan kepada pemegang saham dan laba bersih per saham". Menurut Sarngadharan dan Kumar (2011:149),

"Dividend Payout Ratio (DPR) shows the proportion of earnings per share distributed to the equity shareholders as dividend. The other portion of the earnings per share is being retained for reinvestment purpose in the business. In short, dividend payout ratio indicates the relation of dividend per equity share to earnings per equity share".

Maka dapat disimpulkan Dividend Payout Ratio (DPR) merupakan perbandingan jumlah dividen yang dibayarkan kepada pemegang saham terhadap laba bersih per saham. Dalam rasio ini dapat ditunjukkan persentase laba yang dibagikan kepada pemegang sahamnya.

3. Kebijakan Dividen. Kebijakan dividen merupakan keputusan yang diambil perusahaan untuk menentukan berapa besar bagian dari laba bersih yang diperoleh untuk dibagikan sebagai dividen atau sebagai laba yang ditahan. Kebijakan dividen merupakan sebagian pertimbangan dalam keputusan investasi. Maka dari itu, perusahaan dituntut untuk membagikan dividen sebagai realisasi harapan hasil yang diharapkan investor dalam menginvestasikan dananya dalam membeli saham itu,

Likuiditas. Menurut Gitman dalam Deitiana (2011:59),

"Likuiditas merupakan kemampuan perusahaan untuk memenuhi kewajiban finansial yang berjangka pendek tepat waktunya atau kemampuan perusahaan untuk menyediakan kas atau setara kas, yang ditunjukkan besar kecilnya aktiva lancer, yaitu aktiva yang mudah diubah menjadi kas yang meliputi kas, surat berharga, piutang, persediaan. Likuiditas perusahaan yang seringkali diukur menggunakan rasio lancer menunjukkan kemampuan perusahaan mendanai operasional perusahaan dan melunasi kewajiban jangka pendeknya. Perusahaan yang memiliki likuiditas baik maka memungkinkan pembayaran dividen dengan lebih baik pula".

Menurut Purwaningsih dalam Clarensia, Rahayu, dan Azizah (2013:74). "Likuiditas merupakan kemampuan perusahaan untuk memenuhi kewajiban jangka pendeknya. Makin tinggi tingkat rasio perusahaan tersebut, maka makin tinggi posisi likuiditas perusahaan tersebut".

1. Net Profit Margin (NPM). Menurut Rinati dalam Hutami (2012:110), "Net Profit Margin menunjukkan berapa besar persentase laba bersih yang diperoleh dari setiap penjualan". Menurut Alexandri dalam Rinati (2012:5), "Net Profit Marginadalah rasio yang digunakan unuk menunjukkan kemampuan perusahaan dalam menghasilkan keuntungan bersih setelah dipotong pajak". Lalu menurut Bastian dan Suhardjono dalam Rinati (2012:5),

"Net Profit Margin adalah perbandingan antara laba bersih dengan penjualan. Semakin besar NPM, maka kinerja perusahaan akan semakin produktif, sehingga 
akan meningkatkan kepercayaan investor untuk menanamkan modalnya pada perusahaan tersebut".

2. Return on Equity (ROE). Menurut Mardiyanto dalam Rinati (2012:6), "ROE adalah rasio yang digunakan untuk mengukur keberhasilan perusahaan dalam menghasilkan laba bagi para pemegang saham. ROE dianggap sebagai representasi dari nilai perusahaan". Menurut Fred dan Brigham dalam Rinati (2012:6) "Return on Equity (ROE) is the ratio of net income to common equity: measures the ratio of return on common stockholders investment". Selanjutnya menurut Tambunan dalam Rinati (2012:6), "ROE digunakan untuk mengukur rate of return ekuitas. Para analis sekuritas dan pemegang saham umumnya sangat memperhatikan rasio ini, semakin tinggi ROE yang dihasilkan perusahaan, semakin tinggi harga sahamnya".

3. Price to Book Value (PBV). Menurut Darmadji dan Fakhrudin dalam Stella (2009:101), "Price to Book Value (PBV) menggambarkan seberapa besar pasar menghargai nilai buku suatu saham". Menurut Rogers (2013:64),

"The price to book ratio, or P/B ratio, compares a firm's book value to its current market price. The $P / B$ is derived in one of two ways:

a. The ratio of the firm's market capitalization over the firm's total shareholder equity, or

b. A per share value, the ratio of the firm's current share price over its book value per share, or the ratio of the price per share over the net assets per share".

Harga Saham. Menurut Ayu dan Edy Handoyo dalam Clarensia, Rahayu, dan Azizah (2013:78), "Harga saham adalah harga yang terkandung dalam surat kepemilikan bagian modal berdasarkan penilaian pasar yang dipengaruhi oleh permintaan dan penawaran di bursa efek". Menurut Kesuma dalam Clarensia, Rahayu, dan Azizah (2013:78), "Harga saham adalah nilai nominal penutupan dari penyertaan atau pemilikan seseorang atau badan dalam suatu perusahaan atau perseroan terbatas yang berlaku secara reguler di pasar modal di Indonesia".

Menurut Sunariyah dalam Hutami (2012:106), "Harga saham adalah selembar saham yang berlaku dalam pasar saat ini di bursa efek". Sedangkan menurut Jogiyanto dalam Hutami (2012:106), "Harga saham adalah harga yang terjadi di pasar bursa pada saat tertentu yang ditentukan oleh pelaku pasar dan ditentukan oleh permintaan dan penawaran saham yang bersangkutan di pasar modal".

Macam-Macam Harga Saham. Menurut Sawidji Widoatmojo dalam Hutami (2012:107), Harga saham dapat dibedakan menjadi tiga, yaitu: (1) Harga Nominal adalah harga yang tercantum dalam sertifikat saham yang ditetapkan oleh emiten untuk menilai setiap lembar saham yang dikeluarkan; (2) Harga Perdana dalah harga yang didapatkan pada waktu harga saham tersebut dicatat di bursa efek; (3) Harga Pasar adalah harga jual dari investor yang satu dengan investor yang lain".

Penilaian Harga Saham. Menurut Tandelilin (2010:301),

"Dalam penilaian saham dikenal adanya tiga jenis nilai, yaitu : nilai buku, nilai pasar, dan nilai intrinsik saham. Nilai buku merupakan nilai yang dihitung berdasarkan pembukuan perusahaan penerbit saham (emiten). Nilai pasar adalah nilai saham di pasar, yang ditunjukkan oleh harga saham tersebut di pasar. Sedangkan nilai intrinsik atau dikenal sebagai nilai teoritis adalah nilai saham yang sebenarnya atau seharusnya terjadi”. 
Pengaruh Kebijakan Dividen Terhadap Harga Saham. Clarensia, Rahayu, dan Azizah (2013:79) menguji apakah kebijakan dividen berpengaruh terhadap harga saham. Pengambilan sampel menggunakan purposive sampling. Sampel yang digunakan adalah beberapa perusahaan manufaktur yang terdaftar di BEI dengan periode tahun 2007-2010. Hasil penelitian ini menemukan bahwa kebijakan dividen berpengaruh secara signifikan terhadap harga saham.

Deitiana (2011:63) menguji apakah kebijakan dividen berpengaruh terhadap harga saham. Pengambilan sampel menggunakan purposive sampling. Sampel yang digunakan adalah semua perusahaan LQ 45 di Bursa Efek Indonesia pada periode 2004-2008, yaitu 45 dan yang mengeluarkan dividen secara tetap adalah 20 perusahaan. Hasil penelitian ini menemukan bahwa kebijakan dividen tidak berpengaruh secara signifikan terhadap harga saham. Berdasarkan penelitian di atas, maka penelitian ini akan membuktikan apakah kebijakan dividen berpengaruh terhadap harga saham pada perusahaan manufaktur.

Pengaruh Likuiditas Terhadap Harga Saham. Clarensia, Rahayu, dan Azizah (2013:79) menguji apakah likuiditas berpengaruh terhadap harga saham. Pengambilan sampel menggunakan purposive sampling. Sampel yang digunakan adalah beberapa perusahaan manufaktur yang terdaftar di BEI dengan periode tahun 2007-2010. Hasil penelitian ini menemukan bahwa likuiditas berpengaruh secara signifikan terhadap harga saham.

Deitiana (2011:63) menguji apakah likuiditas berpengaruh terhadap harga saham. Pengambilan sampel menggunakan purposive sampling. Sampel yang digunakan adalah semua perusahaan LQ 45 di Bursa Efek Indonesia pada periode 2004-2008, yaitu 45 dan yang mengeluarkan dividen secara tetap adalah 20 perusahaan. Hasil penelitian ini menemukan bahwa likuiditas tidak berpengaruh secara signifikan terhadap harga saham.

Berdasarkan penelitian di atas, maka penelitian ini akan membuktikan apakah likuiditas berpengaruh terhadap harga saham pada perusahaan manufaktur.

Pengaruh Net Profit Margin (NPM) Terhadap Harga Saham. Hutami (2012:106) menguji apakah Net Profit Margin (NPM) berpengaruh terhadap harga saham. Pengambilan sampel menggunakan purposive sampling. Sampel yang digunakan adalah seluruh perusahaan industri manufaktur yang go public dan aktif di Bursa Efek Indonesia selama tahun 2006-2010 sejumlah 152 perusahaan yang dimana sampel yang memenuhi kriteria adalah 31 perusahaan. Hasil penelitian ini menemukan bahwa Net Profit Margin (NPM) berpengaruh secara signifikan terhadap harga saham.

Serife Ozlen (2014:598) menguji apakah Net Profit Margin (NPM) berpengaruh terhadap harga saham. Sampel yang digunakan adalah 48 perusahaan yang beroperasi dalam 11 sektor yang berbeda pada Istanbul Stock Exchange. Hasil penelitian ini menemukan bahwa Net Profit Margin (NPM) dapat berpengaruh signifikan dan tidak berpengaruh signifikan terhadap harga saham, tergantung dari jenis sektor industrinya.

Rinati (2012:3) menguji apakah Net Profit Margin (NPM) berpengaruh terhadap harga saham. Sampel yang digunakan adalah 11 perusahaan dari 45 perusahaan yang tercantum dalam indeks LQ45 selama periode 2004-2008. Hasil penelitian ini menemukan bahwa Net Profit Margin (NPM) tidak berpengaruh signifikan terhadap harga saham.

Berdasarkan penelitian di atas, penelitian ini akan membuktikan apakah Net Profit Margin (NPM) berpengaruh terhadap harga saham pada perusahaan manufaktur. 
Pengaruh Return on Equity (ROE) Terhadap Harga Saham. Hutami (2012:106) menguji apakah Return on Equity (ROE) berpengaruh terhadap harga saham. Pengambilan sampel menggunakan purposive sampling. Sampel yang digunakan adalah seluruh perusahaan industri manufaktur yang go public dan aktif di Bursa Efek Indonesia selama tahun 2006-2010 sejumlah 152 perusahaan yang dimana sampel yang memenuhi kriteria adalah 31 perusahaan. Hasil penelitian ini menemukan bahwa Return on Equity (ROE) berpengaruh secara signifikan terhadap harga saham.

Rinati (2012:3) menguji apakah Return on Equity (ROE) berpengaruh terhadap harga saham. Sampel yang digunakan adalah 11 perusahaan dari 45 perusahaan yang tercantum dalam indeks LQ45 selama periode 2004-2008. Hasil penelitian ini menemukan bahwa Return on Equity (ROE) tidak berpengaruh signifikan terhadap harga saham. Berdasarkan penelitian di atas, penelitian ini akan membuktikan apakah Return on Equity (ROE) berpengaruh terhadap harga saham pada perusahaan manufaktur.

Pengaruh Price to Book Value (PBV) Terhadap Harga Saham. Stella (2009:98) menguji apakah Price to Book Value (PBV) berpengaruh terhadap harga saham. Sampel yang digunakan adalah 14 saham LQ 45 yang tergolong likuid, dan selalu masuk dalam kategori LQ 45 pada periode 2002-2006. Hasil penelitian ini menemukan bahwa Price to Book Value (PBV) tidak berpengaruh signifikan terhadap harga saham. Permana (2009:2) menguji apakah Price to Book Value (PBV) berpengaruh terhadap harga saham. Hasil penelitian ini menemukan bahwa Price to Book Value (PBV) berpengaruh signifikan terhadap harga saham. Berdasarkan penelitian di atas, penelitian ini akan membuktikan apakah Price to Book Value (PBV) berpengaruh terhadap harga saham pada perusahaan manufaktur.

Kerangka Pemikiran. Kerangka pemikiran untuk mengetahui pengaruh kebijakan dividen, likuiditas, Net Profit Margin (NPM), Return On Equity (ROE), dan Price To Book Value (PBV) terhadap harga saham terdiri dari tiga tahap. Tahap pertama adalah menentukan topik yang akan dibahas dalam penelitian. Tahap kedua yaitu mengumpulkan data dari jurnal penelitian sebelumnya dan melakukan studi kepustakaan yang berkaitan dengan topik mengenai kebijakan dividen, likuiditas, Net Profit Margin (NPM), Return On Equity (ROE), Price To Book Value (PBV), dan harga saham serta mengumpulkan data yang berkaitan dengan masalah yang dibahas dari situs internet.

Kemudian mengidentifikasi obyek penelitian yang terdiri dari Kebijakan Dividen, Likuiditas, Net Profit Margin (NPM), Return On Equity (ROE), Price To Book Value (PBV), dan harga saham. Lalu mengembangkan hipotesis tentang pengaruh setiap variabel yang telah diidentifikasi terhadap harga saham. Setelah mengembangkan hipotesis, maka selanjutnya dilakukan uji statistik deskriptif, uji asumsi klasik dan uji analisis regresi untuk menganalisis hipotesis yang telah dikembangkan. Tahap terakhir adalah membuat kesimpulan dan saran berdasarkan hasil analisis yang telah dilakukan.

Hipótesis. Hipotesis dalam penelitian ini adalah sebagai berikut:

Ha1 : kebijakan dividen berpengaruh terhadap harga saham

$\mathrm{Ha} 2$ : likuiditas berpengaruh terhadap harga saham

Ha3 : Net Profit Margin (NPM) berpengaruh terhadap harga saham

Ha4 : Return On Equity (ROE) berpengaruh terhadap harga saham

Ha5 : Price To Book Value (PBV) berpengaruh terhadap harga saham 
Secara garis besar rumusan hipotesis penelitian dapat dilihat pada gambar 1

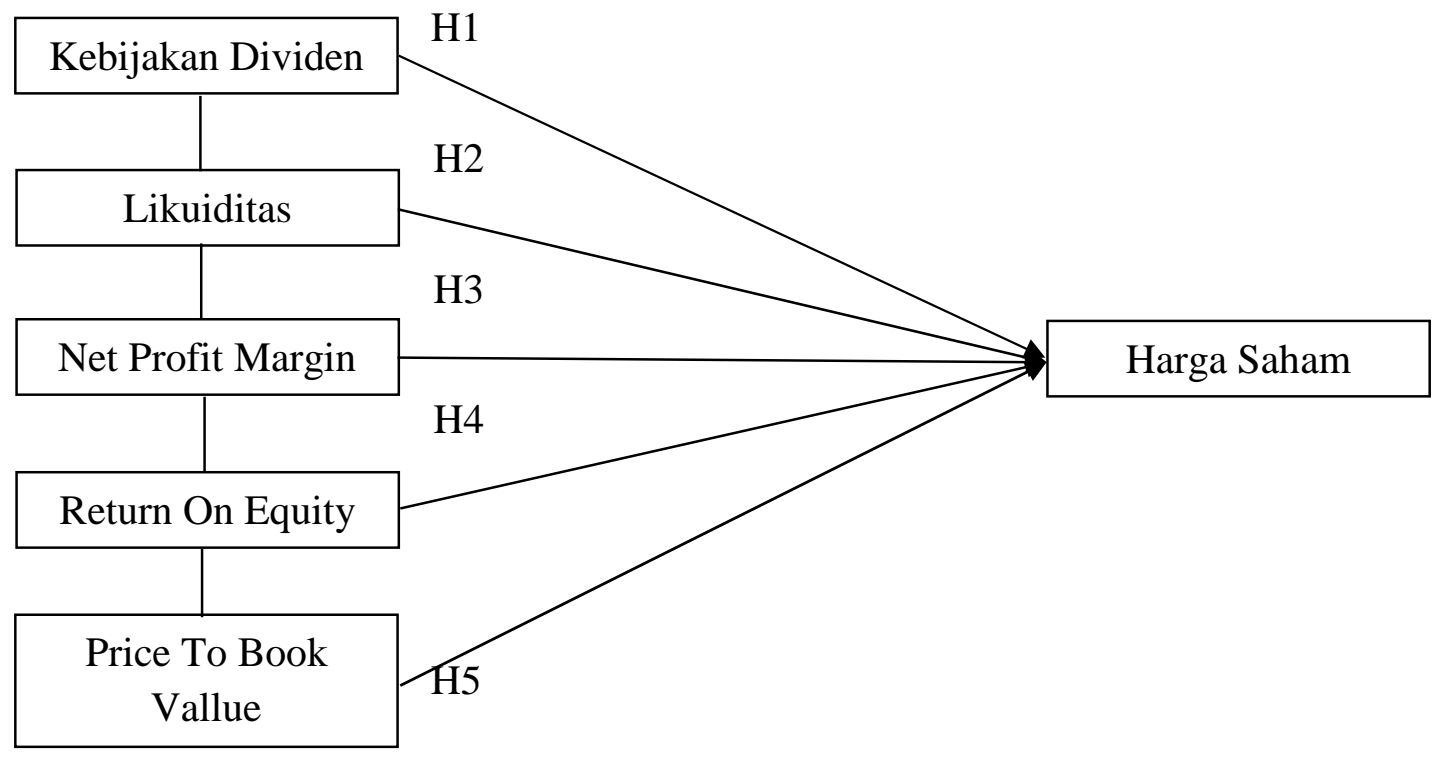

Gambar 1. Perumusan Hipotesis Penelitian

\section{METODE}

Penelitian ini dilakukan pada perusahaan manufaktur yang terdaftar di Bursa Efek Indonesia, dengan mengamati dan menganalisis objek penelitian yang terdiri atas variable -variabel yang diteliti yaitu variabel kebijakan dividen $\left(\mathrm{X}_{1}\right)$, variabel likuiditas $\left(\mathrm{X}_{2}\right)$, variabel net profit margin $\left(\mathrm{X}_{3}\right)$, variabel return on equity $\left(\mathrm{X}_{4}\right)$, variabel price to book value (X), dan variabel harga saham (Y). Variabel $\mathrm{X}_{1}, \mathrm{X}_{2}, \mathrm{X}_{3}, \mathrm{X}_{4}, \mathrm{X}_{5}$ merupakan independent variable, sedangkan variabel $\mathrm{Y}$ merupakan dependent variable.

Populasi dan Teknik Pemilihan Sampel. Populasi yang menjadi objek dalam penelitian ini adalah seluruh perusahaan manufaktur yang go public dan aktif di Bursa Efek Indonesia selama tahun 2010 - 2013 yang berjumlah 141perusahaan. Pengambilan sampel ini dilakukan dengan menggunakan teknik purposive sampling yang merupakan bagian dari pengambilan sampel cara nonprobabilitas yang berarti pemilihan sampel perusahaan berdasarkan kriteria tertentu dengan tujuan untuk mendapatkan sampel yang representatif. Kriteria yang digunakan untuk memilih sampel pada penelitian ini adalah: (1) Perusahaan yang terdaftar di Bursa Efek Indonesia pada tahun 2010 sampai 2013; (2) Perusahaan menerbitkan laporan keuangan yang telah diaudit selama periode pengamatan; (3) Laporan keuangan sampel adalah laporan keuangan yang menggunakan mata uang Indonesia; (4) Perusahaan selalu membagikan dividen selama periode pengamatan; (5) Perusahaan selalu profitable selama periode pengamatan.

Teknik pengumpulan data yang digunakan dalam penelitian ini adalah: (1) Penelitian lapangan (field research). Penelitian lapangan merupakan kegiatan mengumpulkan data sekunder yang berkaitan dengan topik penelitian. Dalam penelitian ini, data yang dikumpulkan dari www.idx.co.id, dan www.sahamok.com. Data yang diperoleh adalah data sekunder berupa dividen, likuiditas, net profit margin, return on equity, price to book value, dan harga saham yang diperoleh dari laporan keuangan perusahaan manufaktur 
yang terdaftar di Bursa Efek Indonesia. (2) Penelitian kepustakaan (library research). Memahami yang berhubungan dengan topik penelitian seperti : jurnal Clarensia, Rahayu, dan Azizah (2013), Deitiana (2011), Hutami (2012), Ozlen (2014), Permana (2009), Rinati (2012), dan Stella (2009). i.

Teknik Pengolahan Data. Penelitian ini menggunakan teknik analisis regresi. Analisis regresi yang digunakan adalah analisis regresi linear berganda dengan menggunakan program aplikasi SPSS 21. Sebelum hasil persamaan regresi linear dianalisa lebih lanjut, terlebih dahulu dilakukan pengujian asumsi klasik atas persamaan regresi untuk memastikan bahwa persamaan regresi layak untuk digunakan. Maka untuk persamaan regresi linear berganda, pengujian asumsi klasik yang dilakukan terdiri dari uji normalitas, uji multikolinearitas, uji heteroskedastisitas, dan uji autokorelasi.

Teknik Pengujian Hipotesis. Untuk menguji pengaruh informasi laba dan arus kas terhadap harga saham digunakan persamaan regresi linear berganda sebagai berikut:

$$
\mathrm{Y}=\beta_{0}+\beta_{1} \mathrm{X}_{1}+\beta_{2} \mathrm{X}_{2}+\beta_{3} \mathrm{X}_{3}+\beta_{4} \mathrm{X}_{4}+\beta_{5} \mathrm{X}_{5}+\varepsilon
$$

Dimana: $Y=$ harga saham; $\beta_{0}=$ konstanta; $\beta_{1}, \beta_{2}, \beta_{3}, \beta_{4}, \beta_{5}=$ koefisien regresi dari masingmasing variabel independen; $\mathrm{X}_{1}=$ kebijakan dividen; $\mathrm{X}_{2}=$ likuididtas; $\mathrm{X}_{3}=$ net profit margin; $\mathrm{X}_{4}=$ return on equity; $\mathrm{X}_{5}=$ price to book value; $\varepsilon=$ error .

\section{HASIL DAN PEMBAHASAN}

Metode analisis deskriptif merupakan metode yang digunakan untuk menganalisis dan menyajikan data kuantitatif yang jumlahnya relatif besar dengan tujuan untuk menggambarkan data tersebut agar dapat dimengerti dengan mudah. Statistik deskriptif menggambarkan data sampel yang digunakan dalam penelitian sehingga dapat diketahui nilai maksimum, minimum, rata-rata, dan standar deviasi masing-masing variabel penelitian.

Nilai maksimum adalah nilai tertinggi sejumlah data yang dianalisis pada suatu periode tertentu. Nilai minimum adalah nilai terendah sejumlah data yang dianalisis pada suatu periode tertentu. Nilai rata-rata / mean adalah nilai rata-rata sejumlah data yang dianalisis pada suatu periode tertentu. Standar deviasi adalah suatu nilai yang menunjukkan variasi data yang dianalisis pada suatu periode tertentu.

Statistik deskriptif lebih berhubungan dengan pengumpulan dan peringkasan data, serta penyajian hasil peringkasan tersebut. Oleh karena itu, pada tahap awal penelitian dilakukan statistik dengan analisis deskriptif yang memiliki kegunaan pokok untuk melakukan pengecekan terhadap input data. Statistik deskriptif menunjukkan ukuran seperti nilai minimum, nilai maksimum, nilai mean, standard deviation, dan ukuran sampel dari setiap variabel yang digunakan dalam penelitian baik variabel dependen maupun variabel independen. Berikut adalah hasil statistik deskriptif selama tahun 20102013.

Hasil statistik deskriptif menunjukkan bahwa jumlah data yang valid dan digunakan dalam penelitian ini adalah 72 data. Kolom minimum menunjukkan data minimum yang ada pada masing-masing variabel. Kolom maksimum menunjukkan data maksimum yang ada pada masing-masing variabel. Kolom mean menyajikan rata-rata untuk masingmasing variabel yang digunakan dalam penelitian ini. Kolom standard deviation merupakan ukuran untuk mengetahui penyebaran data dari mean. 
Tabel 1. Hasil Statistik Deskriptif

\begin{tabular}{lrrrrr}
\hline & N & Minimum & Maximum & Mean & \multicolumn{1}{c}{$\begin{array}{c}\text { Std. } \\
\text { Deviation }\end{array}$} \\
\hline Dividen & 72 & 10.00 & 1280.00 & 211.9972 & 240.52823 \\
Likuiditas & 72 & .31 & 11.74 & 3.2346 & 2.40361 \\
NPM & 72 & .97 & 28.95 & 12.2094 & 6.76928 \\
ROE & 72 & .02 & 1.26 & .2412 & .22835 \\
PBV & 72 & .41 & 46.63 & 4.7883 & 8.68061 \\
Harga Saham & 72 & 310.50 & 55605.00 & 10142.3736 & 12014.82553 \\
Valid N (listwise) & 72 & & & & \\
\hline
\end{tabular}

Dividen yang diindikasikan oleh dividend per shareselama tahun 2010-2013 dengan jumlah sampel sebanyak 72, mempunyai nilai terendah sebesar 10 yang merupakan nilai dividend per share PT Gajah Tunggal Tbk dan PT Trias Sentosa Tbk. Lalu nilai tertinggi dividend per share sebesar 1280 yang merupakan nilai dividend per share PT Gudang Garam Tbk. Nilai rata-rata dividend per share dari 72 perusahaan manufaktur yang terdaftar di Bursa Efek Indonesia selama tahun 2010-2013 adalah 211.9972 dengan standar deviasi atau penyimpangan yang terjadi adalah sebesar 240.52823 .

Likuiditas yang diindikasikan oleh current ratioselama tahun 2010-2013 dengan jumlah sampel sebanyak 72, mempunyai nilai terendah sebesar 0.31 yang merupakan nilai current ratio PT Tempo Scan Pacific Tbk dan nilai tertinggi sebesar 11.74 yang merupakan nilai current ratio PT Mandom Indonesia Tbk. Nilai rata-rata current ratio 72 perusahaan manufaktur yang terdaftar di Bursa Efek Indonesia selama tahun 2010-2013 adalah 3.2346 dengan standar deviasi atau penyimpangan yang terjadi sebesar 2.40361.

Net profit margin selama tahun 2010-2013 dengan jumlah sampel sebanyak 72, mempunyai nilai terendah sebesar 0.97 yang merupakan nilai net profit margin PT Gajah Tunggal Tbk dan nilai tertinggi sebesar 28.95 yang merupakan nilai net profit margin PT Indocement Tunggal Prakarsa Tbk. Nilai rata-rata net profit margin dari 72 perusahaan manufaktur yang terdaftar di Bursa Efek Indonesia selama tahun 2010-2013 adalah 12.2094 dengan standar deviasi atau penyimpangan yang terjadi sebesar 6.76928.

Return on equity selama tahun 2010-2013 dengan jumlah sampel sebanyak 72, mempunyai nilai terendah sebesar 0.02 yang merupakan nilai return on equity PTGajah Tunggal Tbk dan nilai tertinggi sebesar 1.26 yang merupakan nilai return on equity PT Unilever Indonesia Tbk. Nilai rata-rata return on equity dari 72 perusahaan manufaktur yang terdaftar di Bursa Efek Indonesia selama tahun 2010-2013 adalah -0.2412 dengan standar deviasi atau penyimpangan yang terjadi sebesar 0.22835 .

Price to book value selama tahun 2010-2013 dengan jumlah sampel sebanyak 72, mempunyai nilai terendah sebesar 0.41 yang merupakan nilai price to book value PT Trias Sentosa Tbk dan nilai tertinggi sebesar 46.63 yang merupakan nilai price to book value PT Unilever Indonesia Tbk. Nilai rata-rata price to book value dari 72 perusahaan manufaktur yang terdaftar di Bursa Efek Indonesia selama tahun 2010-2013 adalah 4.7883 dengan standar deviasi atau penyimpangan yang terjadi sebesar 8.68061.

Harga saham selama tahun 2010-2013 dengan jumlah sampel sebanyak 72, nilai terendah sebesar 310.50 merupakan nilai harga saham PT Trias Sentosa Tbk dan nilai tertinggi sebesar 55605 merupakan nilai harga saham PT Gudang Garam Tbk. Nilai ratarata harga saham dari 72 perusahaan manufaktur yang terdaftar di Bursa Efek Indonesia 
selama tahun 2010-2013 adalah 10142.3736 dengan standar deviasi atau penyimpangan yang terjadi sebesar 12014.82553.

Uji Asumsi Klasik. Salah satu syarat untuk bisa menggunakan persamaan regresi adalah terpenuhinya asumsi klasik. Analisis regresi merupakan analisis yang bertujuan untuk menentukan model yang paling sesuai bagi data serta dapat digunakan untuk menyelidiki hubungan antara dua variabel atau lebih. Suatu model regresi yang baik dan layak dipakai untuk memprediksi variabel dependen berdasarkan pada masukan variabel independen adalah model regresi yang memenuhi pengujian asumsi klasik yaitu asumsi normalitas, multikolinearitas, autokorelasi, dan heteroskedastisitas. Setelah pengujian asumsi klasik terpenuhi, baru dapat dilakukan pengujian hipotesis.

Pengujian normalitas menggunakan One - Sample Kolmogorov - Smirnov Test dengan nilai signifikansi 5\%. Residual data dikatakan terdistribusi secara normal apabila nilai signifikansi lebih besar dari atau sama dengan 0,05 dan sebaliknya apabila nilai signifikansi lebih kecil dari 0,05 maka dapat disimpulkan residual data tidak terdistribusi secara normal.

Pengujian ini dimaksudkan untuk menguji apakah dalam model regresi, variabel pengganggu atau residual memiliki distribusi normal. Model regresi yang baik menggunakan data yang terdistribusi normal atau mendekati normal. Uji normalitas dilakukan dengan menggunakan uji Kolmogorov Smirnov dengan menggunakan tingkat keyakinan sebesar 95\%. Data dinyatakan terdistribusi secara normal apabila nilai signifikansi lebih besar dari 0,05 dan apabila nilai signifikansi lebih kecil dari 0,05 maka data dinyatakan tidak terdistribusi secara normal.

Tabel 2. Hasil Uji Normalitas

One-Sample Kolmogorov-Smirnov Test

\begin{tabular}{|c|c|c|}
\hline & & $\begin{array}{c}\text { Unstandardized } \\
\text { Residual }\end{array}$ \\
\hline $\mathrm{N}$ & & 72 \\
\hline \multirow{2}{*}{ Normal Parameters a.b } & Mean & .0000000 \\
\hline & Std. Deviation & 6549.035138 \\
\hline \multirow{3}{*}{ Most Estreme Differences } & Absolute & .139 \\
\hline & Positive & .139 \\
\hline & Negative & .122 \\
\hline Kolmogorov-Smirnov Z & & 1.176 \\
\hline Asymp.Sig. (2-tailed) & & .126 \\
\hline
\end{tabular}

a. Test distribution is Normal

b. Calculated from data

Nilai signifikansi pada Tabel 2 adalah 0.126. Nilai signifikansi $0.126>0.05$ menunjukkan bahwa tidak terdapat masalah normalitas dan data terdistribusi secara normal.

Uji multikolinearitas dilakukan untuk melihat apakah antara variabel independen terdapat korelasi signifikan satu dengan yang lain. Jika terdapat korelasi, artinya terdapat masalah multikolinearitas antar variabel independen. Suatu model regresi yang baik seharusnya tidak memiliki korelasi di antara variabel independennya dengan tujuan untuk menghindari kebiasan dalam proses pengambilan keputusan mengenai pengaruh pada uji parsial masing-masing variabel independen terhadap variabel dependen. 
Cara mendeteksi adanya multikolinearitas adalah dengan melihat nilai Variance Inflation Factor (VIF) dan tolerance masing-masing variabel independen. Pedoman untuk model regresi yang bebas multikolinearitas yaitu angka Variance Inflation Factor (VIF) lebih kecil dari 10 dan angka tolerance lebih besar dari 0,10. Hasil pengujian multikolinearitas dapat dilihat pada Tabel 3.

Tabel 3. Hasil Uji Multikolinearitas Coefficients $^{\mathrm{a}}$

\begin{tabular}{llll}
\hline Model & & \multicolumn{2}{c}{ Collinearity Statistics } \\
\cline { 3 - 4 } & & Tolerance & VIF \\
\hline 1 & Dividen & .872 & 1.147 \\
& Likuiditas & .732 & 1.366 \\
& NPM & .570 & 1.755 \\
& ROE & .383 & 2.609 \\
& PBV & .447 & 2.238 \\
\hline
\end{tabular}

a. Dependent Variabel: Harga Saham

Tabel 3 menunjukkan nilai Variance Inflation Factor (VIF) dan tolerance masingmasing variabel independen. Besarnya Variance Inflation Factor (VIF) untuk dividend per share adalah sebesar 1.147, besarnya Variance Inflation Factor (VIF) untuk current ratio adalah sebesar 1.366, besarnya Variance Inflation Factor (VIF) untuk net profit margin adalah sebesar 1.755, besarnya Variance Inflation Factor (VIF) untuk return on equity adalah sebesar 2.609, dan besarnya Variance Inflation Factor (VIF) untuk price to book value adalah sebesar 2.238. Hasil tersebut menunjukkan bahwa pada model regresi tidak terjadi masalah multikolinearitas karena seluruh variabel independen memenuhi pedoman model regresi yang bebas multikolinearitas yaitu mempunyai Variance Inflation Factor (VIF) lebih kecil dari 10.

Tabel 3 menunjukkan besarnya nilai tolerance untuk dividend per share adalah sebesar 0.872 , untuk current ratio adalah sebesar 0.732 , untuk net profit margin adalah sebesar 0.570 ,untuk return on equity adalah sebesar 0.383 , dan untuk price to book value adalah sebesar 0.447. Hasil tersebut menunjukkan bahwa pada model regresi tidak terjadi masalah multikolinearitas karena seluruh variabel independen memenuhi pedoman regresi yang bebas multikolinearitas yaitu mempunyai nilai tolerance lebih besar dari 0.10

Uji autokorelasi bertujuan untuk mengetahui apakah dalam sebuah model regresi ada korelasi antara kesalahan pengganggu pada periode $t$ dengan kesalahan pengganggu pada periode t-1 (sebelumnya). Apabila terjadi korelasi, maka pada model regresi tersebut terdapat masalah autokorelasi.

Autokorelasi muncul karena pengamatan yang berurutan sepanjang waktu berkaitan satu dengan yang lainnya. Masalah ini timbul karena kesalahan pengganggu tidak bebas dari satu pengamatan ke pengamatan lainnya. Model regresi yang baik tidak terdapat autokorelasi. Apabila angka Durbin Watson berada di antara -2 sampai +2 maka dapat disimpulkan tidak terdapat autokorelasi.

Uji autokorelasi bertujuan untuk menguji apakah dalam suatu model regresi terdapat korelasi antara kesalahan pengganggu pada periode $t$ dengan kesalahan pengganggu pada periode t-1 (sebelumnya). Cara mendeteksi adanya autokorelasi yaitu dengan menggunakan uji Durbin Watson. Model regresi dikatakan tidak memiliki masalah 
autokorelasi apabila koefisien parameter (nilai signifikansi) untuk residual lag di atas 0,05. Hasil uji autokorelasi dapat dilihat pada Tabel 4.

\begin{tabular}{|c|c|c|c|c|c|}
\hline & \multicolumn{5}{|c|}{$\begin{array}{c}\text { Tabel 4. Hasil Uji Autokorelasi } \\
\text { Model Summaryb }^{\mathrm{b}}\end{array}$} \\
\hline Model & $\mathrm{R}$ & R Square & $\begin{array}{l}\text { Adjusted R } \\
\text { Square }\end{array}$ & $\begin{array}{l}\text { Std. Error of } \\
\text { the Estimate }\end{array}$ & $\begin{array}{l}\text { Durbin- } \\
\text { Watson }\end{array}$ \\
\hline 1 & $.838^{\mathrm{a}}$ & .703 & .680 & 6792.57633 & 1.995 \\
\hline
\end{tabular}

a. Predictors: (Constant), PBV, NPM, Dividen, Likuiditas, ROE

b. Dependen Variabel: Harga Saham

Hasil uji autokorelasi dengan uji Durbin Watson menunjukkan nilai sebesar 1.995. Nilai ini akan kita bandingkan dengan nilai tabel signifikansi 5\%, jumlah sampel 72 (n) dan jumlah variabel independen $5(\mathrm{~K}=5)$. Maka diperoleh nilai dU sebesar 1.7688, dan nilai (4-dU) sebesar 2.2312. Nilai uji Durbin Watson sebesar 1.995 yang berada di tengahtengah dU dan (4-dU) sehingga disimpulkan tidak terdapat autokorelasi. $(1.7688<1.995<$ 2.2312)

Uji heteroskedastisitas digunakan untuk menguji apakah pada model regresi terjadi ketidaksamaan variance dan residual dari satu pengamatan ke pengamatan lainnya. Jika variance dan residual dari satu pengamatan ke pengamatan lainnya tetap maka disebut homokedastisitas. Apabila sebaliknya, maka disebut heteroskedastisitas. Model regresi yang baik adalah apabila tidak terdapat heteroskedastisitas.

Uji heteroskedastisitas bertujuan untuk menguji apakah dalam model regresi terjadi ketidaksamaan variance dari residual satu pengamatan ke pengamatan lain. Model regresi yang baik adalah yang tidak terjadi heteroskedastisitas. Ada tidaknya heteroskedastisitas dilihat dari nilai signifikansi untuk masing-masing variabel independen. Jika variabel independen memiliki nilai signifikansi lebih kecil dari 0,05 maka dapat disimpulkan bahwa pada model regresi terdapat heteroskedastisitas. Sebaliknya jika variabel independen memiliki nilai signifikansi lebih besar dari 0,05 maka dapat disimpulkan bahwa pada model regresi tidak terdapat heteroskedastisitas. Hasil pengujian heteroskedastisitas dapat dilihat pada tabel berikut.

Tabel 5. Hasil Uji Heteroskedastisitas

Coefficients $^{\mathrm{a}}$

\begin{tabular}{llrrrrr}
\hline \multirow{2}{*}{ Model } & \multicolumn{2}{c}{$\begin{array}{c}\text { Unstandardized } \\
\text { Coefficients }\end{array}$} & \multicolumn{2}{c}{$\begin{array}{c}\text { Standardized } \\
\text { Coefficients }\end{array}$} & \multicolumn{1}{c}{ t } & \multirow{2}{*}{ Sig. } \\
\cline { 2 - 5 } & \multicolumn{1}{c}{ B } & \multicolumn{1}{c}{ Std. Error } & \multicolumn{1}{c}{ Beta } & & \\
\hline \multirow{2}{*}{1} & (Constant) & 7971.352 & 31704.259 & & .251 & .804 \\
& Dividen & 44.277 & 34.095 & .278 & 1.299 & .206 \\
& Likuiditas & 3937.918 & 7088.993 & .159 & .555 & .584 \\
NPM & -1646.155 & 1790.361 & -.274 & -.919 & .367 \\
ROE & 174081.576 & 183408.441 & .718 & .949 & .352 \\
PBV & -2293.514 & 4464.281 & -.381 & -.514 & .612 \\
\hline
\end{tabular}

a. Dependent Variabel: Absres

Hasil uji heteroskedastisitas menunjukkan nilai signifikansi dividend per share adalah sebesar $0.206>0.05$ berarti untuk dividend per share tidak terdapat heteroskedastisitas, nilai signifikansi current ratio adalah sebesar $0.584>0.05$ berarti untuk current ratio tidak terdapat heteroskedastisitas, nilai signifikansi net profit margin 
adalah sebesar $0.367>0.05$ berarti untuk net profit margin tidak terdapat heteroskedastisitas, nilai signifikansi return on equityadalah sebesar $0.352>0.05$ berarti untuk return on equity tidak terdapat heteroskedastisitas, dan nilai signifikansiprice to book value adalah sebesar $0.612>0.05$ berarti untuk price to book value juga tidak terdapat heteroskedastisitas.

Uji Hipotesis. Setelah melakukan uji asumsi klasik, dapat disimpulkan bahwa data terdistribusi secara normal, tidak terjadi multikolinearitas pada model regresi, tidak terdapat masalah autokorelasi pada model regresi yang digunakan dan tidak mengandung heteroskedastisitas. Ini berarti bahwa model regresi baik dan layak digunakan untuk memprediksi variabel dependen yaitu harga saham berdasarkan pada masukan variabel independen yaitu kebijakan dividen, likuiditas, net profit margin, return on equity, dan price to book value. Tahap selanjutnya yaitu melakukan uji hipotesis dengan tingkat keyakinan sebesar $95 \%$.

Analisis regresi adalah hubungan secara linear antara dua atau lebih variabel independen dengan variabel dependen. Untuk mengetahui apakah terdapat pengaruh kebijakan dividen, likuiditas, net profit margin, return on equity, dan price to book value terhadap harga saham maka digunakan persamaan regresi. Hasil perhitungan untuk persamaan regresi dengan menggunakan metode enter dapat dilihat dari tabel di bawah ini:

Tabel 6. Koefisien Regresi

\begin{tabular}{llcc}
\hline Model & & \multicolumn{2}{c}{ Unstandardized Coefficients } \\
\cline { 3 - 4 } & & B & Std. Error \\
\hline 1 & (constant) & 255.042 & 4137.419 \\
& Dividen & 40.662 & 3.592 \\
& Likuiditas & 741.583 & 1356.530 \\
& NPM & .337 & 4.760 \\
& ROE & 3.685 & 181.525 \\
& PBV & 94.610 & 146.784 \\
\hline
\end{tabular}

a. Dependent Variabel: Harga Saham

Berdasarkan Tabel 6 model regresi selama tahun 2010-2013 adalah sebagai berikut:

$$
Y=255.042+40.662 X 1+741.583 X 2+0.337 X 3+3.685 X 4+94.610 X 5
$$

Keterangan: $\mathrm{Y}=$ Harga Saham; X1= Dividen; X2= Likuiditas; X3 = Net Profit Margin (NPM); X4 = Return on Equity (ROE); X5 = Price to Book Value (PBV)

Persamaan regresi di atas dapat diinterpretasikan sebagai berikut: Nilai constant sebesar 255.042 menunjukkan apabila dividen, likuiditas, net profit margin, return on equity, dan price to book value sama dengan nol, maka harga saham bernilai positif. Harga saham bernilai positif artinya harga saham tanpa dividen, likuiditas, net profit margin, return on equity, dan price to book value bernilai positif sebesar 255.042

Koefisien regresi dividen sebesar 40.662 artinya akan terjadi perubahan yang searah antara dividen dengan harga saham. Setiap peningkatan dividen sebesar satu satuan akan menambah nilai harga saham sebesar 40.662 satuan dengan likuiditas, NPM, ROE, dan PBV bernilai tetap. Sebaliknya apabila dividen turun sebesar satu satuan, maka nilai harga saham akan turun sebesar 40.662 satuan.

Koefisien regresi likuiditas sebesar 741.583 artinya akan terjadi perubahan yang searah antara likuiditas dengan harga saham. Setiap peningkatan likuiditas sebesar satu 
satuan akan menambah nilai harga saham sebesar 741.583 satuan dengan dividen, NPM, ROE, dan PBV bernilai tetap. Sebaliknya apabila likuiditas turun sebesar satu satuan, maka nilai harga saham akan turun sebesar 741.583 satuan.

Koefisien regresi net profit margin sebesar 0.337 artinya akan terjadi perubahan yang searah antara net profit margin dengan harga saham. Setiap peningkatan net profit margin sebesar satu satuan akan menambah nilai harga saham sebesar 0.337 satuandengan dividen, likuiditas, ROE, dan PBV bernilai tetap. Sebaliknya apabila net profit margin turun sebesar satu satuan, maka nilai harga saham akan turun sebesar 0.337 satuan.

Koefisien regresi return on equity sebesar 3.685 artinya akan terjadi perubahan yang searah antara return on equity dengan harga saham. Setiap peningkatan return on equity sebesar satu satuan akan menambah nilai harga saham sebesar 3.685 satuan dengan dividen, likuiditas, NPM, dan PBV bernilai tetap. Sebaliknya apabila return on equity turun sebesar satu satuan, maka nilai harga saham akan turun sebesar 3.685 satuan.

Koefisien regresi price to book value sebesar 94.610 artinya akan terjadi perubahan yang searah antara price to book value dengan harga saham. Setiap peningkatan price to book value sebesar satu satuan akan menambah nilai harga saham sebesar 94.610 satuan dengan dividen, likuiditas, NPM, dan ROE bernilai tetap. Sebaliknya apabila price to book value turun sebesar satu satuan, maka nilai harga saham akan turun sebesar 94.610 satuan.

Uji Statistik t. Uji t pada dasarnya menunjukkan seberapa jauh pengaruh satu variabel independen secara individual dalam menerangkan variasi variabel dependen. Uji $t$ dilakukan dengan melihat nilai signifikansinya, jika nilai signifikansi lebih besar dari 0.05 maka Ha ditolak yang artinya variabel independen secara individual tidak mempunyai pengaruh yang signifikan terhadap variabel dependen dengan tingkat keyakinan sebesar 95\%. Sebaliknya jika nilai signifikansi lebih kecil dari 0.05 maka Ha diterima yang artinya variabel independen secara individual mempunyai pengaruh yang signifikan terhadap variabel dependen dengan tingkat keyakinan sebesar $95 \%$.

Hasil uji statistik t dapat dilihat pada Tabel 7.

Tabel 7. Hasil Uji Statistik t

\begin{tabular}{|c|c|c|c|c|c|c|}
\hline \multirow{2}{*}{\multicolumn{2}{|c|}{ Model }} & \multicolumn{2}{|c|}{$\begin{array}{c}\text { Unstandardized } \\
\text { Coefficients }\end{array}$} & \multirow{2}{*}{$\begin{array}{c}\text { Standardized } \\
\text { Coefficients }\end{array}$} & \multirow[t]{2}{*}{$\mathrm{t}$} & \multirow[t]{2}{*}{ Sig. } \\
\hline & & $\mathrm{B}$ & Std. Error & & & \\
\hline \multirow[t]{6}{*}{1} & (Constant) & 255.042 & 4137.419 & & .062 & 951 \\
\hline & Dividen & 40.662 & 3.592 & .814 & 11.32 & .000 \\
\hline & Likuiditas & 741.583 & 1356.530 & .045 & .547 & .586 \\
\hline & NPM & .337 & 4.760 & .006 & .071 & 944 \\
\hline & ROE & 3.685 & 181.525 & .002 & .020 & .984 \\
\hline & PBV & 94.610 & 146.784 & .068 & .645 & .521 \\
\hline
\end{tabular}

a. Dependent Variabel: Harga Saham

Berdasarkan Tabel 7 hasil uji pengaruh dividen terhadap harga saham mempunyai nilai signifikansi sebesar 0.000 yang berarti Hal diterima karena nilai signifikansi lebih kecil dari 0.05. Dapat disimpulkan bahwa dividen mempunyai pengaruh yang signifikan terhadap harga saham. Hasil ini konsisten dengan penelitian Clarenzia, Rahayu, dan Azizah (2013) dan Hutami (2012) namun tidak konsisten dengan penelitian y Deitiana (2011). Semakin tinggi dividen biasanya mengindikasikan bahwa perusahaan memiliki 
harga saham yang tinggi disertai dengan dividen yang tinggi. Sebaliknya semakin rendah dividen yang dibagikan maka harga saham perusahaan tersebut juga rendah.

Hasil uji pengaruh likuiditas terhadap harga saham mempunyai nilai signifikansi sebesar 0.585 yang berarti Ha2 ditolak karena nilai signifikansi lebih besar dari 0.05 . Dapat disimpulkan bahwa likuiditas tidak mempunyai pengaruh yang signifikan terhadap harga saham. Hasil ini konsisten dengan penelitian Deitiana (2011), namun tidak konsisten dengan penelitian Clarenzia, Rahayu, dan Azizah (2013).

Hasil uji pengaruh net profit margin terhadap harga saham mempunyai nilai signifikansi sebesar 0.944 yang berarti Ha3 ditolak karena nilai signifikansi lebih besar dari 0.05. Maka dapat disimpulkan bahwa net profit margin tidak mempunyai pengaruh yang signifikan terhadap harga saham. Hasil ini konsisten dengan penelitian Rinati (2012), namun tidak konsisten dengan penelitian Hutami (2012).

Hasil uji pengaruh return on equity terhadap harga saham mempunyai nilai signifikansi sebesar 0.984 yang berarti Ha4 ditolak karena nilai signifikansi lebih besar dari 0.05. Maka dapat disimpulkan bahwa return on equity tidak mempunyai pengaruh yang signifikan terhadap harga saham. Hasil ini konsisten dengan penelitian Rinati (2012) namun tidak konsisten dengan penelitian Hutami (2012).

Hasil uji pengaruh price to book value terhadap harga saham mempunyai nilai signifikansi sebesar 0.521 yang berarti Ha5 ditolak karena nilai signifikansi lebih besar dari 0.05. Maka dapat disimpulkan bahwa price to book value tidak mempunyai pengaruh yang signifikan terhadap harga saham. Hasil ini konsisten dengan penelitian Stella (2009), namun tidak konsisten dengan Permana (2009).

Uji Statistik F. Uji F menunjukkan apakah semua variabel bebas yang dimasukkan dalam model mempunyai pengaruh secara bersama-sama terhadap variabel dependen. Uji $\mathrm{F}$ dilakukan dengan melihat nilai $\mathrm{F}$, apabila nilai $\mathrm{F}$ lebih besar daripada $\mathrm{F}$ tabel dan nilai signifikansi lebih kecil dari 0,05 maka Ha dapat diterima pada tingkat keyakinan sebesar 95\% yang menyatakan bahwa model regresi dapat digunakan untuk memprediksi variabel dependen atau dapat dikatakan bahwa semua variabel independen secara serentak dan signifikan mempengaruhi variabel dependen.

Uji $\mathrm{F}$ menunjukkan apakah semua variabel independen yang dimasukkan dalam model mempunyai pengaruh secara bersama-sama terhadap variabel dependen. Uji $F$ dilakukan dengan melihat nilai $\mathrm{F}$, apabila nilai $\mathrm{F}$ lebih besar daripada 4 dan nilai signifikansi lebih kecil dari 0,05 maka Ha dapat diterima pada tingkat keyakinan sebesar 95\% yang menyatakan bahwa model regresi dapat digunakan untuk memprediksi variabel dependen atau dapat dikatakan bahwa semua variabel independen secara serentak dan signifikan mempengaruhi variabel dependen. Berikut ini adalah tabel yang menunjukkan hasil uji statistik F.

Tabel 8. Hasil Uji Statistik F ANOVA $^{\mathrm{a}}$

\begin{tabular}{|c|c|c|c|c|c|c|}
\hline & Model & Sum if Squares & $\mathrm{df}$ & Mean square & $\mathrm{F}$ & Sig. \\
\hline \multirow[t]{3}{*}{1} & Regression & 7192838988 & 5 & 1438567798 & 31.064 & $.000^{\mathrm{b}}$ \\
\hline & Residual & 3056439314 & 66 & 46309686.58 & & \\
\hline & Total & 10249278303 & 71 & & & \\
\hline
\end{tabular}

a. Dependent Variabel: Harga Saham

b. Predictors: (Constant), PBV, NPM, Dividen, Likuiditas, ROE 
Hasil uji statistik F menunjukkan nilai F hitung sebesar 31.064 sedangkan F tabel sebesar 2.37. Nilai $F$ hitung> Nilai $F$ tabel maka model regresi dapat digunakan untuk memprediksi harga saham. Nilai signifikansi dari hasil uji $\mathrm{F}$ sebesar 0.000 , nilai signifikansi ini lebih kecil dari 0.05 maka model regresi dapat digunakan untuk memprediksi harga saham.

Analisis korelasi (R) digunakan untuk mengetahui kuat atau lemahnya hubungan antara dua atau lebih variabel independen terhadap variabel dependen. Nilai $R$ semakin mendekati satu berarti hubungan yang terjadi semakin kuat, sebaliknya nilai $\mathrm{R}$ semakin mendekati nol maka hubungan yang terjadi semakin lemah. Analisis koefisien determinasi (R Square) digunakan untuk mengukur seberapa jauh kemampuan model dalam menerangkan variasi variabel dependen. Berikut ini adalah tabel yang menunjukkan analisis koefisien korelasi dan analisis koefisien determinasi:

Tabel 9. Hasil Uji Koefisien Korelasi dan Koefisien Determinasi Model Summary

\begin{tabular}{ccccc}
\hline Model & $\mathrm{R}$ & R Square & $\begin{array}{c}\text { Adjusted R } \\
\text { Square }\end{array}$ & $\begin{array}{c}\text { Std. Error of the } \\
\text { Estimate }\end{array}$ \\
\hline 1 & $.838^{\mathrm{a}}$ & .702 & .679 & 6805.12208 \\
\hline
\end{tabular}

a. Predictors: (Constant), PBV, NPM, dividen, Likuiditas, ROE

Tabel 9 menunjukkan korelasi antara dividen, likuiditas, net profit margin, return on equity, dan price to book value terhadap harga saham. Angka $\mathrm{R}$ yang didapat dari hasil analisis adalah 0.838 yang berarti bahwa hubungan antara dividen, likuiditas, net profit margin, return on equity, dan price to book value terhadap harga saham adalah positif dan kuat karena nilai R lebih besar dari 0.5. Besarnya Adjusted R Square adalah 0.679 yang berarti bahwa $67.9 \%$ variasi harga saham dapat dijelaskan oleh variasi dari dividen, likuiditas, net profit margin, return on equity, dan price to book value sedangkan sisanya sebesar $32.1 \%$ dijelaskan oleh faktor-faktor yang lain di luar model penelitian.

\section{PENUTUP}

Simpulan. Uji hipotesis dengan hasil uji $\mathrm{t}$ yang menunjukkan dividen mempunyai pengaruh yang signifikan terhadap harga saham. Likuiditas, Net profit margin, Return on equity, Price to book value tidak mempunyai pengaruh yang signifikan terhadap harga saham. Uji F menunjukkan semua variabel independen mempunyai pengaruh secara bersama-sama terhadap variabel dependen.

Saran. Pada penelitian ini sampel perusahaan yang digunakan 18 perusahaan manufaktur di BEI, periode pengamatan4 tahun,variabel bebas yang digunakan dalam mempengaruhi harga saham dengan lima variable yaitu kebijakan dividen, likuiditas, net profit margin, return on equity, danprice to book value. Maka beberapa saran untuk penelitian selanjutnya sebaiknya menambah jumlah data dengan memperpanjang periode pengamatan atau dengan menambahkan variable independen lainnya yang belum digunakan dalam penelitian ini . 


\section{DAFTAR RUJUKAN}

Clarensia, J., Rahayu, S., \& Azizah, N. (2013) "Pengaruh likuiditas, profitabilitas, pertumbuhan penjualan, dan kebijakan dividen terhadap harga saham". http://fe.budiluhur.ac.id/wp-content/uploads/2013/10/5e-JURNAL-5-SRI.pdf.

Deitiana, T. (2011) "Pengaruh rasio keuangan, pertumbuhan penjualan dan dividen terhadap harga saham". Jurnal Bisnis dan Akuntansi. Vol. 1, (1). April, hal. 57-66.

Harahap, S. S. (2006) Analisa Kritis Atas Laporan Keuangan Edisi Keempat. Jakarta: PT RajaGrafindo Persada.

Hutami, R. P. (2012) "Pengaruh dividend per share, return on equity dan net profit margin terhadap harga saham perusahaan industri manufaktur yang tercatat di Bursa Efek Indonesia periode 2006-2010”. Jurnal Nominal. Vol. 1, (1).

Ikatan Akuntan Indonesia. (2012) Standar Akuntansi Keuangan Per 1 Juni 2012. Jakarta: Salemba Empat.

Kieso, Weygandt, J., \& Warfield, T. D. (2011) Intermediate Accounting IFRS Edition. New Jersey: John Wiley \& Sons.

Ozlen, S. (2014) "The effect of company fundamentals on stock values". European Researcher. (Vol. 71).

Permana, Y. (2009) "Pengaruh fundamental keuangan, tingkat bunga dan tingkat inflasi terhadap pergerakan harga saham". Jurnal Akuntansi-Universitas Gunadarma. September.

Rinati, I. (2012) Pengaruh net profit margin (NPM), return on assets (ROA) dan return on equity (ROE) terhadap harga saham pada perusahaan yang tercantum dalam indeks LQ45.

http://www.gunadarma.ac.id/library/articles/graduateleconomy/2009/Artikel_20205 626.pdf.

Rogers, J. (2013) Strategy, Value and Risk: A Guide to Advanced Financial Management Third Edition. New York: Palgrave Macmillan.

Sarngadharan, M., \& Kumar, S. R. (2011) Financial Analysis for Management Decisions. New Delhi: PHI Learning Private Limited.

Stella. (2009) "Pengaruh price to earnings ratio, debt to equity ratio, return on asset dan price to book value terhadap harga pasar saham". Jurnal Bisnis dan Akuntansi. Vol. 1, (2)., hal. 97-106.

Sugiono, A., Soenarno, Y. N., \& Kusumawati, S. M. (2010) Akuntansi dan Laporan Keuangan untuk Bisnis Skala Kecil. Jakarta: Grasindo.

Tandelilin, E. (2010). Portofolio dan Investasi Edisi Pertama. Yogyakarta: Kanisius.

Weygandt, J. J., Kieso, D. E., \& Kimmel, P. D. (2009) Accounting Principles 8th Edition. Canada: John Wiley \& Sons. 